\title{
PENINGKATAN PEMAHAMAN KONSEP DAN HASIL BELAJAR MATERI PENYESUAIAN MAKHLUK HIDUP DALAM PEMBELAJARAN KOOPERATIF TIPE THINK-PAIR-SHARE DIPADU DENGAN MODEL PICTURE AND PICTURE YANG DIKEMBANGKAN MELALUI LESSON STUDY
}

\author{
Citra Marina \\ SMK Darussalam Martapura Kabupaten Banjar \\ Email: marinacitra13@gmail.com
}

\begin{abstract}
ABSTRAK
Dari hasil wawancara dengan guru mata pelajaran IPA di SD Muhammadiyah 8 DAU, bahwa dari 31 orang siswa pada kelas VA, dapat dikatakan $45 \%$ dari jumlah siswa memiliki hasil belajar yang rendah. Selain itu, guru pengajar mengaku jarang menggunakan media pembelajaran seperti gambar-gambar hewan, tumbuhan dll. Penelitian ini bertujuan: (1) Untuk mengetahui penerapan pembelajaran kooperatif tipe TPS dipadukan dengan model Picture and Picture untuk meningkatkan pemahaman konsep dan hasil belajar dalam materi Penyesuaian Makhluk Hidup pada siswa kelas V A SD Muhammadiyah 8 DAU yang dikembangkan melalui Lesson Study. (2) Untuk mengetahui peningkatan pembelajaran kooperatif tipe TPS dipadukan dengan model P\&P untuk meningkatkan pemahaman konsep dan hasil belajar siswa dalam konsep Penyesuaian Makhluk Hidup pada siswa kelas V SD Muhammadiyah 8 DAU yang dikembangkan melalui Lesson Study. Jenis penelitian ini adalah penelitian tindakan kelas yang dikembangkan melalui Lesson Study, menggunakan pembelajaran kooperatif tipe TPS dipadu dengan model P\&P. LS dilakukan sebanyak dua kali pertemuan, sedangkan untuk PTK dilaksanakan satu kali pertemuan. Penelitian ini menggunakan analisis deskriptif kualitatif. Pelaksanaan dilapangan, penerapan tahapan-tahapan pembelajaran TPS yang dipadukan dengan model P\&P sudah terlaksana dengan optimal. Berdasarkan hasil analisis data untuk pemahaman konsep siswa pada pelaksanaan tindakan, siswa yang memperoleh nilai $<70$ sebanyak 6 orang (20\%), sedangkan yang mendapat nilai $>70$ sebanyak 24 orang $(80 \%)$ dari 30 siswa yang mengikuti evaluasi. Untuk hasil belajar siswa, siswa yang memperoleh nilai > SKM sebanyak 27 orang (90\%), sedangkan yang mendapat nilai < nilai SKM sebanyak 3 orang (10\%) dari 30 siswa.
\end{abstract}

Kata Kunci: Think-Pair-Share (TPS), Picture and Picture (P\&P), Lesson Study.

\begin{abstract}
Based on the result of interview with the teachers of Natural Science stream in SD Muhammadiyah $8 \mathrm{Dau}$, from 31 students of grade Va, it can be said that $45 \%$ of the students have low study result. Besides, the teachers stated that they are rarely using learning media such as animal or plant pictures, etc. The research purposes are: (1) to find out the application of cooperative learning TPS type combined with Picture and Picture model to raise the comprehension of concept in living organism adjustment material on the students of grade Va SD Muhammadiyah 8 Dau, developed through Lesson Study; (2) to find out the development of cooperative learning TPS type combined with P\&P Model to develop students learning result in living organism adjustment material on students of grade Va SD Muhammadiyah 8 Dau, developed through Lesson Study. The type of research
\end{abstract}


is class action developed through Lesson Study, using cooperative learning TPS type combined with P\&P model. LS was conducted twice while PTS was conducted in one meeting. The research uses qualitative descriptive analysis. The field application, phases application, TPS learning combined with P\&P Model have been done optimally. According to the data analysis, the result for students' concept comprehension in application action, the total students who received $<70$ point are 6 people $(20 \%)$, while the students who receive $>70$ grade are 24 people (80\%) from 30 students who followed the evaluation for students' learning result. Students who received more than standard minimum criteria are 27 people (90\%), while the students who received grade less than minimum criteria are 3 people (10\%) from 30 students.

Keywords: Think-Pair-Share (TPS), Picture and Picture (P\&P), Lesson Study.

\section{PENDAHULUAN}

Proses pembelajaran atau proses belajar mengajar pada dasarnya adalah interaksi atau hubungan timbal balik antara guru dan siswa dalam situasi pendidikan. Dalam proses belajar mengajar pasti terdapat beberapa kelemahan yang mempengaruhi hasil belajar siswa. Oleh karena itu, guru dalam mengajar dituntut kesabaran, keuletan, dan sikap terbuka disamping kemampuan dalam situasi belajar mengajar yang lebih aktif. Demikian pula dari siswa dituntut adanya semangat dan dorongan untuk belajar.

Ilmu Pengetahuan Alam (IPA) menyediakan berbagai pengalaman belajar bagi siswa untuk memahami konsep dan proses pengetahuan alam dan menekankan agar siswa menjadi pelajar aktif dan luwes. Pembelajaran IPA SD kelas V pada bab penyesuaian makhluk hidup mempunyai konsep yang seringkali sulit diingat dan dipahami oleh siswa. Metode dan model pembelajaran yang digunakan dalam pembelajaran IPA sangat banyak. Tiap metode dan model pembelajaran memiliki kelebihan dan kekurangan yang berbeda. Dalam penelitian ini menggunakan pembelajaran kooperatif. Pembelajaran kooperatif (Cooperative Learning) merupakan sistem pengajaran yang memberi kesempatan kepada anak didik untuk bekerja sama dengan sesama siswa dalam tugas-tugas yang terstruktur. Pembelajaran kooperatif adalah suatu model pembelajaran dimana sistem belajar dan bekerja dalam kelompok-kelompok kecil yang berjumlah 4-6 orang secara kolaboratif sehingga dapat merangsang siswa lebih bergairah dalam belajar (Isjoni, 2010).

Pembelajaran kooperatif yang dipilih adalah tipe Think-Pair-Share (TPS) karena tipe ini dirasa lebih tepat untuk kegiatan berpikir, berpasangan dan berbagi sesuai kegiatan yang akan dilakukan siswa. TPS cenderung bersifat abstrak karena mengandalkan kemampuan berpikir, sedangkan Picture and Picture (P\&P) bersifat konkrit maka dari itu pembelajaran TPS ini sangat cocok dipadukan dengan model P\&P karena seusia anak SD cenderung berpikir konkrit. Model pembelajaran Think-Pair-Share adalah salah satu model pembelajaran kooperatif dengan pendekatan struktur. Model pembelajaran ini memberi kesempatan pada siswa untuk bekerja sendiri serta bekerja sama dengan orang lain (Suprijono, 2009). Model Pembelajaran Picture and Picture adalah model pembelajaran menggunakan media gambar dalam proses pembelajaran yaitu dengan cara memasang/mengurutkan gambargambar menjadi urutan yang logis. Melalui 
Tabel 1. Langkah umum model pembelajaran kooperatif

\begin{tabular}{|c|l|l|}
\hline No. & \multicolumn{1}{|c|}{ Fase } & \multicolumn{1}{c|}{ Tingkah Laku Guru } \\
\hline $\mathbf{1}$ & $\begin{array}{l}\text { Fase I } \\
\text { Menyampaikan tujuan dan } \\
\text { memotivasi siswa }\end{array}$ & $\begin{array}{l}\text { Guru menyampaikan semua tujuan pembelajaran yang } \\
\text { ingin dicapai pada pelajaran tersebut dan memotivasi } \\
\text { siswa belajar. }\end{array}$ \\
\hline $\mathbf{2}$ & $\begin{array}{l}\text { Fase II } \\
\text { Menyajikan informasi }\end{array}$ & $\begin{array}{l}\text { Guru menyajikan informasi kepada siswa dengan jalan } \\
\text { demonstrasi atau lewat bahan bacaan. }\end{array}$ \\
\hline $\mathbf{3}$ & $\begin{array}{l}\text { Fase III } \\
\text { Mengorganisasikan siswa ke } \\
\text { dalam kelompok belajar }\end{array}$ & $\begin{array}{l}\text { Guru menjelaskan kepada siswa bagaimana caranya } \\
\text { membentuk kelompok belajar dan membantu setiap } \\
\text { kelompok agar melakukan transisi secara efisien. }\end{array}$ \\
\hline $\mathbf{4}$ & $\begin{array}{l}\text { Fase IV } \\
\text { Membimbing kelompok bekerja } \\
\text { dan belajar }\end{array}$ & $\begin{array}{l}\text { Guru membimbing kelompok-kelompok belajar pada } \\
\text { saat mereka mengerjakan tugas mereka. }\end{array}$ \\
\hline $\mathbf{5}$ & $\begin{array}{l}\text { Fase V } \\
\text { Evaluasi }\end{array}$ & $\begin{array}{l}\text { Guru mengevaluasi hasil belajar yang telah dipelajari } \\
\text { atau masing-masing kelompokmempresentasikan hasil } \\
\text { kerjanya. }\end{array}$ \\
\hline $\mathbf{6}$ & $\begin{array}{l}\text { Fase VI } \\
\text { Memberikan penghargaan }\end{array}$ & $\begin{array}{l}\text { Guru mencari cara-cara untuk menghargai baik upaya } \\
\text { maupun hasil belajar individu dan kelompok. }\end{array}$ \\
\hline
\end{tabular}

Sumber: Ibrahim,dkk., (2000)

cara seperti ini diharapkan siswa mampu berpikir dengan logis sehingga pembelajaran menjadi bermakna (Yusti, 2009).

Dari hasil wawancara dengan guru mata pelajaran IPA di SD Muhammadiyah 8 DAU, bahwa dari 31 orang siswa pada kelas VA, dapat dikatakan $45 \%$ dari jumlah siswa memiliki hasil belajar yang rendah. Selain itu, guru pengajar mengaku jarang menggunakan media pembelajaran seperti gambar-gambar hewan, tumbuhan dll. Hasil belajar ini tentunya dipengaruhi oleh tingkat pemahaman konsep pada materi yang diajarkan. Faktor lain yang mempengaruhi adalah motivasi siswa yang sangat kurang dalam belajar. Untuk meningkatkan pemahaman konsep dan hasil belajar siswa merupakan tugas guru sebagai pengajar. Pemahaman konsep merupakan tingkat kemampuan yang mengharapkan peserta didik mampu memahami arti/ konsep, situasi serta fakta yang diketahui, serta dapat menjelaskan dengan menggunakan kata-kata sendiri sesuai dengan pengetahuan yang dimilikinya dengan tidak mengubah arti (Kurnaeni, 2008). Hasil belajar siswa adalah kemampuan-kemampuan yang dimiliki siswa setelah ia menerima pengalaman belajarnya, hasil belajar yang dimaksud dalam penelitian ini adalah berupa skor tes yang diberikan pada setiap akhir siklus (Sudjana, 2005).

Berdasarkan Undang-Undang No. 14 tahun 2005 tentang Guru dan Dosen, pasal 2 ayat 1 menyatakan bahwa "kedudukan" guru adalah sebagai tenaga "profesional". Seseorang yang menyatakan dirinya profesional harus terus menerus meningkatkan layanan profesinya untuk meningkatkan kemaslahatan anak didiknya. Kalau dulu dianggap cukup apabila siswa hanya menguasai aspekaspek kognitif saja dalam pembelajaran sekarang hal itu sangatlah tidak memadai. Siswa juga harus menguasai berbagai kecakapan hidup yang menurut UNESCO 
dirumuskan dalam bentuk empat pilar pendidikan yaitu learning to be, learning to know, learning to do, dan learning to live together.

Untuk mengatasi kelemahan pelatihan yang kurang menekankan pada pasca pelatihan diperlukan model pembinaan yang berfokus pada upaya pemberdayaan sesuai kapasitas serta permasalahan yang dihadapi masingmasing guru. Model tersebut adalah Lesson Study (LS). Menurut Slamet Mulyana dalam Sudrajat (2008), memberikan rumusan tentang Lesson Study sebagai salah satu model pembinaan profesi pendidik melalui pengkajian pembelajaran secara kolaboratif dan berkelanjutan berlandaskan pada prinsippsrinsip kolegalitas dan mutual learning untuk membangun komunitas belajar.

Dengan demikian, Lesson Study bukan metode atau strategi pembelajaran, tetapi kegiatan Lesson Study dapat menerapkan metode atau strategi pembelajaran yang sesuai dengan situasi, kondisi, permasalahan yang dihadapi guru. Lesson Study dilaksanakan dalam tiga tahap, yaitu plan (perencanaan), do (pelaksanaan), dan see (refleksi). Penelitian ini adalah penelitian lanjutan sebelumnya berupa penelitian tindakan kelas. Penelitian lanjutan ini akan dikembangkan melalui lesson study. Semua perangkat pembelajaran berupa RPP, kegiatan pembelajaran akan disusun oleh team work yang terdiri dari peneliti, guru, kepala sekolah serta pihak dari luar yaitu dosen.

Berdasarkan uraian diatas, peneliti tertarik untuk melanjutkan penelitian sebelumnya yang berupa penelitian tindakan kelas, tetapi akan dikembangkan melalui Lesson Study dengan judul: "Peningkatan Pemahaman Konsep dan
Hasil Belajar Materi Penyesuaian Makhluk Hidup dalam Pembelajaran Kooperatif Tipe Think-Pair-Share Dipadukan dengan Model Picture and Picture yang Dikembangkan Melalui Lesson Study".

Berdasarkan latar belakang yang telah diuraikan di atas dapat dirumuskan beberapa masalah, antara lain:

1. Bagaimanakah penerapan pembelajaran kooperatif tipe TPS dipadukan dengan model P\&P untuk meningkatkan pemahaman konsep dan hasil belajar terhadap mata pelajaran IPA materi Penyesuaian Makhluk Hidup pada siswa kelas V A SD Muhammadiyah 8 DAU yang dikembangkan melalui LS?

2. Bagaimanakah peningkatan pemahaman konsep dan hasil belajar siswa melalui pembelajaran kooperatif tipe TPS dipadukan dengan model P\&P terhadap mata pelajaran IPA materi Penyesuaian Makhluk Hidup pada siswa kelas V A SD Muhammadiyah 8 DAU yang dikembangkan melalui LS?

Penelitian ini dilakukan dengan tujuan untuk menjawab permasalahan sebagaimana telah dirumuskan di atas. Secara terperinci, tujuan dari penelitian ini adalah sebagai berikut:

1. Untuk mengetahui penerapan pembelajaran kooperatif tipe TPS dipadukan dengan model P\&P untuk meningkatkan pemahaman konsep dan hasil belajar dalam materi Penyesuaian Makhluk Hidup pada siswa kelas V A SD Muhammadiyah 8 DAU yang dikembangkan melalui LS.

2. Untuk mengetahui peningkatan pemahaman konsep dan hasil belajar siswa melalui pembelajaran kooperatif tipe TPS dipadukan dengan model P\&P dalam konsep Penyesuaian 
Makhluk Hidup pada siswa kelas V SD Muhammadiyah 8 DAU yang dikembangkan melalui LS.

Penelitian yang akan dilaksanakan ini diharapkan berguna bagi beberapa pihak terkait, antara lain:

1. Bagi Guru

Memperoleh pengalaman yang bervariasi dalam menerapkan pembelajaran kooperatif tipe TPS yang dipadukan dengan model P\&P untuk meningkatkan pemahaman konsep dan hasil belajar siswa dalam mata pelajaran IPA yang dikembangkan melalui LS.

2. Bagi siswa

Hasil penelitian ini dapat dilakukan dalam proses pembelajaran oleh guru sehingga akan memberikan pengalaman belajar yang berbeda dari pembelajaran yang biasa dilakukan di kelas.
3. Bagi peneliti lanjutan

Penelitian ini diharapkan dapat menjadi masukan bagi peneliti berikutnya untuk meneliti Penelitian Tindakan Kelas yang dikembangkan melalui LS terhadap berbagai aspek dalam pembelajaran.

\section{METODE}

Penelitian ini merupakan penelitian tindakan kelas (PTK) yang dilakukan secara bersiklus. PTK mencakup tahapan yaitu perencanaan, tindakan, observasi dan refleksi. Penelitian tindakan kelas dilaksanakan dengan mengikuti prosedur penelitian berdasarkan prinsip Kemmis \& Mc. Taggart dalam Mulyasa (2009) dengan menggunakan prosedur kerja yang dipandang sebagai siklus spiral yang meliputi kegiatan perencanaan, tindakan, observasi, refleksi seperti tampak pada gambar dibawah ini:

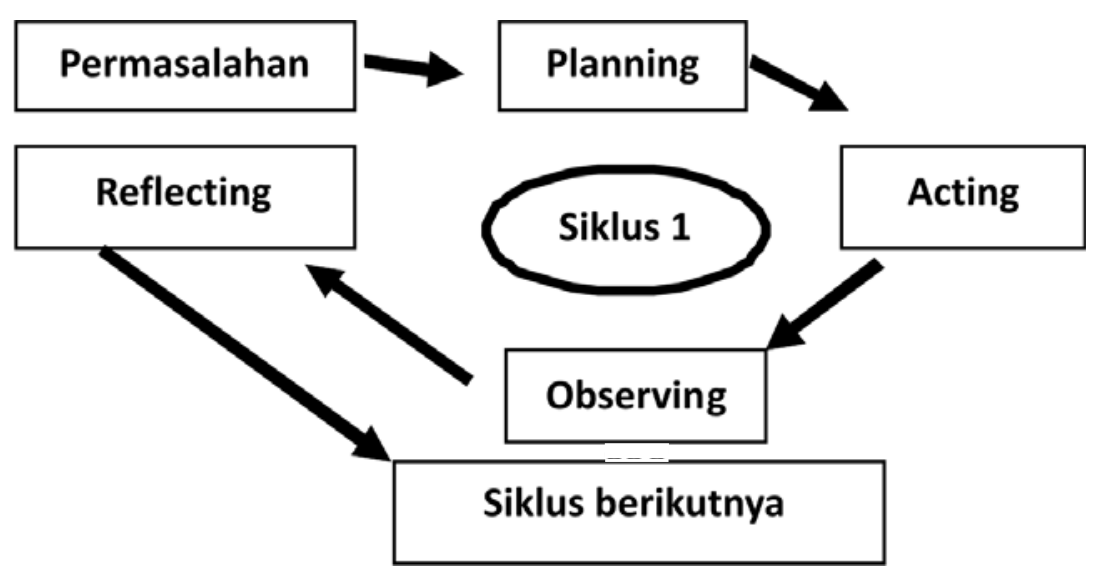

\section{Gambar 1. Modifikasi Siklus Penelitian Tindakan Kelas Model Kemmis \& Taggart dari Mulyasa (2009)}

Jumlah siklus dalam PTK sangat bergantung pada masalah yang akan diselesaikan. Siklus-1 dalam penelitian ini tidak akan dilanjutkan kedalam siklus-2 apabila permasalahan siklus-1 sudah terselesaikan. Indikator terselesaikannya masalah tersebut ada tiga, yaitu: pertama, proses pembelajaran kurang optimal yang diamati melalui keterlaksanaan sintaks perpaduan Think-Pair-Share (TPS) dengan model Picture and Picture (P\&P). Kedua, peningkatan pemahaman konsep apabila skor tingkat pemahaman konsep belum mencapai KKM. Pemahaman konsep siswa berupa kemampuan kognitif yang diukur melalui tes formatif yang 
disusun peneliti bersama guru dengan tingkatan kognitif pada C1, C2, dan C3. Untuk mengetahui peningkatan pemahaman konsep yang diukur oleh peneliti hanya tingkat kognitif C2. Ketiga, peningkatan hasil belajar apabila skor hasil belajar belum mencapai kriteria ketuntasan belajar. Peningkatan hasil belajar yang diukur oleh peneliti adalah semua tingkatan kognitif yang telah dibuat yaitu soal-soal dengan tingkat kognitif C1, C2 dan C3. Setiap satu kali pertemuan dalam tahap perencanaan harus dilakukan tahapan Lesson Study (LS) yaitu plan-do-see.

Perpaduan TPS dengan model P\&P dikarenakan TPS cenderung bersifat abstrak karena mengandalkan kemampuan berpikir, sedangkan P\&P bersifat konkrit maka dari itu pembelajaran TPS ini sangat cocok dipadukan dengan model P\&P karena seusia anak SD cenderung berpikir konkrit. Berdasarkan pendapat tersebut, maka sintaks TPS dipadukan dengan P\&P meliputi delapan langkah sebagai berikut: (1) memberikan pertanyaan yang berhubungan dengan materi penyesuaian makhluk hidup; (2) membagikan gambar serta kertas buffalo yang sudah terdapat tabel penyesuaian makhluk hidup; (3) menugaskan siswa untuk menempelkan gambar dan mengisi tabel yang ada pada kertas buffalo; (4) mengorganisasikan siswa untuk berpasangan dan mendiskusikan apa yang sudah mereka kerjakan; (5) meminta beberapa pasangan untuk berbagi didepan kelas; (6) menanyakan alasan pemikiran gambar yang sudah dicocokkan dengan konsep; (7) dari alasan tersebut guru mulai menanamkan konsep/materi sesuai kompetensi yang akan dicapai; (8) guru memberikan kesimpulan.

Agar menghasilkan kualitas pembelajaran yang lebih baik maka penelitian tindakan kelas ini dipadukan dengan LS. Menurut Styler dan Hiebert dalam Sparks (1999), LS adalah suatu proses kolaboratif pada sekelompok guru ketika mengidentifikasi masalah pembelajaran, merancang suatu skenario pembelajaran, salah seorang guru membelajarkan peserta didik sesuai skenario, sementara yang lain sebagai observer, mengevaluasi dan merevisi skenario. LS dilaksanakan dalam tiga tahap, pertama plan (perencanaan), do (pelaksanaan), see (refleksi).

Pada tahap perencanaan sebelum masuk pada tahap tindakan, dilakukan LS untuk penyusunan silabus, RPP dan perangkat pembelajaran serta penentuan guru model. Dilanjutkan pada tahap tindakan dalam PTK untuk melaksanakan skenario sesuai dengan RPP yang sudah divalidasi dari tahap pelaksanaan LS. Tahap selanjutnya yaitu mengobservasi pencapaian dalam pembelajaran kooperatif tipe TPS dipadukan dengan model P\&P yang sudah dilakukan sesuai skenario, dilanjutkan tahap refleksi menganalisis data yang diperoleh selama proses pembelajaran. Rancangan penelitian tindakan kelas yang dikembangkan melalui LS dapat dilihat seperti gambar dibawah ini: 


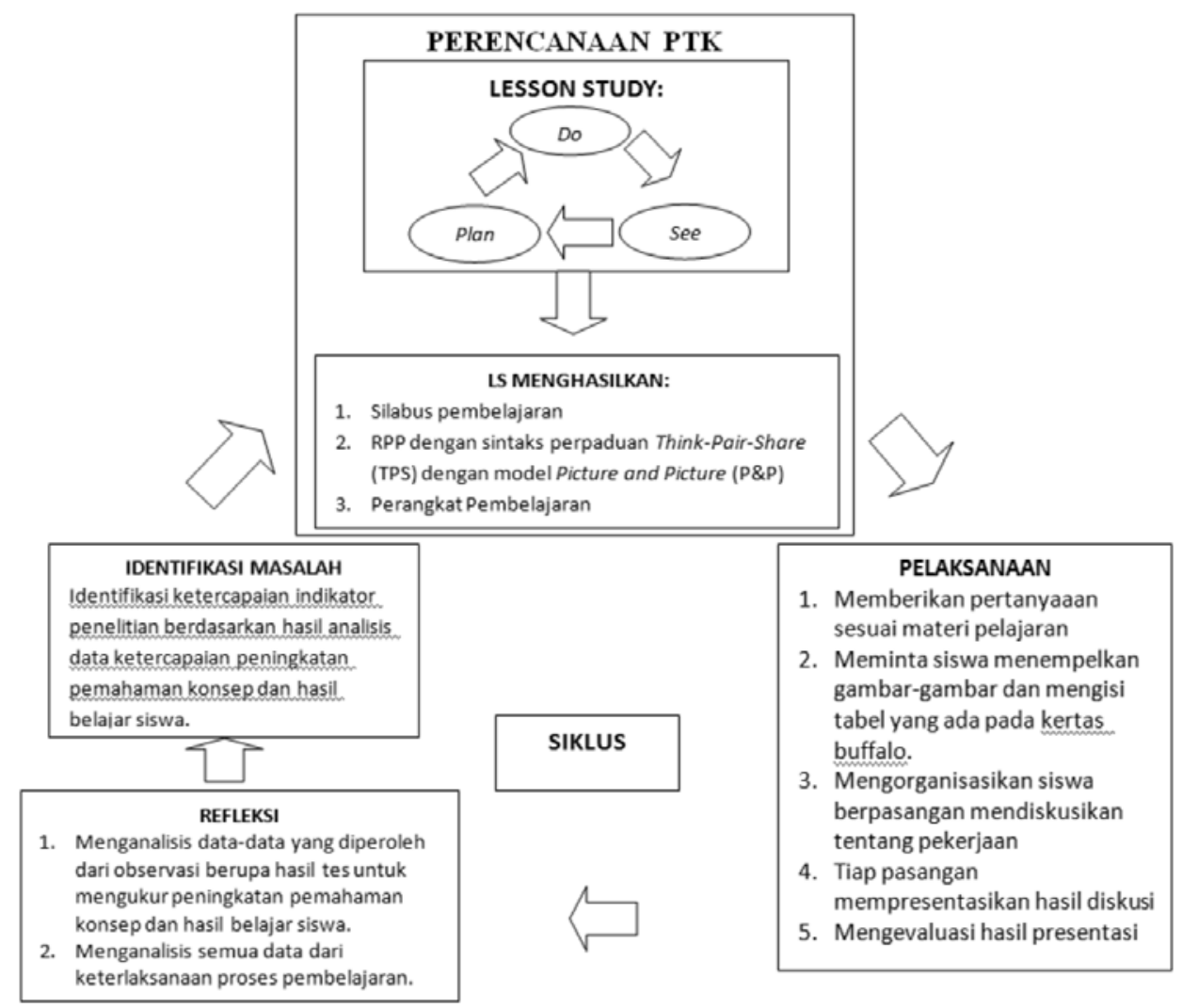

Gambar 2. Siklus PTK yang dikembangkan melalui LS

HASIL DAN PEMBAHASAN

Tabel 2. Data Hasil Refleksi Lesson Study Pertama

\begin{tabular}{ll}
\hline \multicolumn{1}{c}{ Aspek } & \multicolumn{1}{c}{ Refleksi } \\
\hline $\begin{array}{l}\text { a. Keterlaksanaan Tahapan- } \\
\text { tahapan TPS yang } \\
\text { dipadukan dengan model } \\
\text { P\&P }\end{array}$ & \\
\hline $\begin{array}{l}\text { 1. Memberikan pertanyaan } \\
\text { terkait materi penyesuaian } \\
\text { makhluk hidup. }\end{array}$ & $\begin{array}{l}\text { Siswa tidak memberikan respon yang cukup } \\
\text { baik terhadap pertanyaan yang diberikan guru } \\
\text { hal ini dikarenakan pertanyaan tidak dituliskan } \\
\text { pada papan tulis. }\end{array}$ \\
$\begin{array}{ll}\text { Membagikan berbagai } \\
\text { gambar serta kertas bufallo }\end{array}$ & $\begin{array}{l}\text { Siswa masih belum hafal dengan pasangannya } \\
\text { sehingga pembagian gambar belum terlaksana } \\
\text { dengan baik. Pembagian gambar akan lebih } \\
\text { pang sudah terdapat tabel } \\
\text { penyesuaian makhluk hidup. }\end{array}$ \\
$\begin{array}{ll}\text { optimal apabila dibagikan saat siswa sudah } \\
\text { dalam posisi berpasangan. }\end{array}$ \\
$\begin{array}{l}\text { Menugaskan siswa untuk } \\
\text { menempelkan gambar dan }\end{array}$ & $\begin{array}{l}\text { Beberapa siswa masih kebingungan mencari } \\
\text { pasangannya. }\end{array}$ \\
kertas buffalo yang ada pada & \\
\hline
\end{tabular}

JINoP (Jurnal Inovasi Pembelajaran), Volume 2, Nomor 1, Mei 2016, hal. 256-269 


\begin{tabular}{|c|c|}
\hline Aspek & Refleksi \\
\hline $\begin{array}{l}\text { 4. Mengorganisasikan siswa } \\
\text { untuk berpasangan dan } \\
\text { mendiskusikan apa yang } \\
\text { sudah mereka kerjakan }\end{array}$ & $\begin{array}{l}\text { Ada beberapa siswa yang kurang aktif, tetapi } \\
\text { tidak sedikit pula yang memiliki kerjasama } \\
\text { yang baik antar pasangan. }\end{array}$ \\
\hline $\begin{array}{l}\text { 5. Meminta kepada beberapa } \\
\text { pasangan untuk berbagi di } \\
\text { depan kelas tentang apa } \\
\text { yang sudah didiskusikan }\end{array}$ & $\begin{array}{l}\text { Siswa masih ada yang malu-malu saat } \\
\text { mempresentasikan hasil kerja mereka. Jumlah } \\
\text { pasangan yang presentasi masih terlalu sedikit. }\end{array}$ \\
\hline $\begin{array}{l}\text { 6. Guru menanyakan alasan } \\
\text { pemikiran gambar yang } \\
\text { sudah ditempelkan dan isian } \\
\text { pada tabel penyesuaian } \\
\text { makhluk hidup }\end{array}$ & $\begin{array}{l}\text { Bukan hanya guru yang bertanya tetapi ada } \\
\text { beberapa siswa yang berani bertanya kepada } \\
\text { pasangan yang presentasi. }\end{array}$ \\
\hline $\begin{array}{l}\text { 7. Dari alasan pemikiran siswa, } \\
\text { guru mulai menanamkan } \\
\text { konsep/materi sesuai } \\
\text { kompetensi yang akan } \\
\text { dicapai }\end{array}$ & $\begin{array}{l}\text { Siswa dituntun oleh guru untuk menemukan } \\
\text { konsep-konsep penting melalui tanyajawab. }\end{array}$ \\
\hline $\begin{array}{l}\text { 8. Guru memberikan } \\
\text { kesimpulan }\end{array}$ & $\begin{array}{l}\text { Guru sudah dapat memberikan kesimpulan } \\
\text { secara keseluruhan hasil diskusi siswa }\end{array}$ \\
\hline \multicolumn{2}{|l|}{ b. Komponen Pembelajaran } \\
\hline 1. Guru & $\begin{array}{l}\text { Persentase aktivitas guru selama proses } \\
\text { pembelajaran }=78,15 \% \text { berada pada kategori } \\
\text { baik }\end{array}$ \\
\hline 2. Siswa & $\begin{array}{l}\text { Rata-rata persentase aktivitas siswa dari lima } \\
\text { indikator penilaian selama proses pembelajaran } \\
=75 \% \text { berada pada kategori baik }\end{array}$ \\
\hline
\end{tabular}

Tabel 3. Data Hasil Refleksi Lesson Study Kedua

\begin{tabular}{|c|c|c|}
\hline \multicolumn{2}{|r|}{ Aspek } & Refleksi \\
\hline a. & $\begin{array}{l}\text { Keterlaksanaan Tahapan- } \\
\text { tahapan TPS yang dipadu- } \\
\text { kan dengan model P\&P }\end{array}$ & \\
\hline 1. & $\begin{array}{l}\text { Memberikan pertanyaan } \\
\text { terkait materi penyesuaian } \\
\text { makhluk hidup. }\end{array}$ & $\begin{array}{l}\text { Siswa memberikan respon yang cukup baik } \\
\text { terhadap pertanyaan yang diberikan guru. Dan } \\
\text { pertanyaan yang diberikan dituliskan pada } \\
\text { papan tulis. }\end{array}$ \\
\hline & $\begin{array}{l}\text { Mengorganisasikan siswa } \\
\text { untuk berpasangan }\end{array}$ & $\begin{array}{l}\text { Siswa tidak kebingungan dengan pasangannya } \\
\text { seperti pada pertemuan sebelumnya. }\end{array}$ \\
\hline 3. & $\begin{array}{l}\text { Membagikan berbagai } \\
\text { gambar serta kertas bufallo } \\
\text { yang sudah terdapat tabel } \\
\text { penyesuaian makhluk hidup. }\end{array}$ & $\begin{array}{l}\text { Gambar dibagikan setelah siswa pada posisi } \\
\text { sudah berpasangan sehingga tidak ada } \\
\text { kesulitan bagi guru maupun siswa. }\end{array}$ \\
\hline
\end{tabular}

Citra Marina, Peningkatan Pemahaman Konsep dan Hasil Belajar Materi Penyesuaian Makhluk Hidup dalam Pembelajaran Kooperatif Tipe Think-Pair-Share Dipadu dengan Model Picture and Picture yang Dikembangkan Melalui Lesson Study 
Aspek

4. Menugaskan siswa untuk menempelkan gambar dan mengisi tabel yang ada pada kertas buffalo

5. Menugaskan siswa untuk mendiskusikan hasil penempelan gambar dan isian tabel yang sudah dikerjakan

6. Meminta kepada beberapa pasangan untuk berbagi di depan kelas

7. Guru menanyakan alasan pemikiran gambar yang sudah ditempelkan dan isian pada tabel penyesuaian makhluk hidup

8. Dari alasan pemikiran siswa, guru mulai menanamkan konsep/materi sesuai kompetensi yang akan dicapai

9. Guru memberikan kesimpulan
Refleksi

Siswa terlihat lebih aktif dan siswa sudah cukup terbiasa dengan kegiatan menempelkan gambar dan mengisi tabel sehingga siswa tidak mengalami kesulitan melaksanakan apa yang ditugaskan oleh guru.

Ada beberapa siswa yang tidak mendiskusikan hasil pekerjaannya dikarenakan siswa berdiskusi saat pekerjaan mereka telah terselesaikan. Kegiatan diskusi sepertinya lebih efektif saat penempelan gambar dan pengisian tabel.

Beberapa siswa yang presentasi menunjukkan percaya diri yang tinggi, sudah tidak malumalu lagi presentasi didepan kelas.

Beberapa siswa dapat memberikan penjelasan sesuai konsep yang benar.

Siswa sangat antusias karena guru mencoba menanamkan konsep melalui tanyajawab, sehingga siswa memberikan respon positif.

Guru sudah dapat memberikan kesimpulan secara keseluruhan hasil diskusi siswa

\section{b. Komponen Pembelajaran \\ 1. Guru}

2. Siswa
Persentase aktivitas guru selama proses pembelajaran $=82,6 \%$ berada pada kategori baik

Rata-rata persentase aktivitas siswa dari lima indikator penilaian selama proses pembelajaran $=75,36 \%$ berada pada kategori baik

\section{Pemahaman Konsep}

Berdasarkan hasil pengoreksian lembar jawaban soal tes formatif untuk pemahaman konsep pada tingkatan soal C2 dapat diketahui bahwa masing-masing siswa memiliki tingkat pemahaman konsep yang berbeda-beda. Sesuai dengan indikator peningkatannya, siswa dikatakan memiliki pemahaman konsep yang baik apabila nilai hasil tes formatif khusus soalsoal tingkatan C2 yang diperoleh siswa > Standar Kelulusan Minimal (SKM) yaitu 70. Siswa yang nilainya $>$ Standar Kelulusan Minimal maka siswa tersebut dinyatakan tidak tuntas untuk nilai pemahaman konsepnya. Jumlah siswa secara 
keseluruhan ada 31 anak tetapi ada 1 anak yang tidak hadir.

Dari 30 siswa yang hadir, ada 24 siswa yang memperoleh nilai pemahaman konsep mencapai SKM > 70, sementara ada 6 siswa yang memperoleh nilai pemahaman konsep dibawah SKM yaitu $<70$. Bagi siswa yang mendapat nilai pemahaman konsep dibawah SKM maka siswa tersebut dinyatakan tidak tuntas. Data tersebut selanjutnya dianalisis dengan menggunakan rumus ketuntasan pemahaman konsep untuk mengetahui persentase ketuntasan pemahaman konsep klasikal siswa.

Tabel 4. Data Nilai Ketuntasan Pemahaman Konsep Klasikal

\begin{tabular}{ccc}
\hline \multirow{2}{*}{ Prestasi Siswa } & \multicolumn{2}{c}{ Keterangan } \\
\cline { 2 - 3 } & Jumlah Siswa & Persentase \\
\hline Nilai $<70$ & 6 & $20 \%$ \\
Nilai $\geq 70$ & 24 & $80 \%$ \\
Tuntas Pemahaman Konsep & 24 & $80 \%$ \\
Tidak Tuntas Pemahaman Konsep & 6 & $20 \%$ \\
Jumlah siswa & 30 & \\
Rata-rata & 78,96 & $75 \%$ \\
Ketuntasan secara klasikal & $>22$ & \\
\hline
\end{tabular}

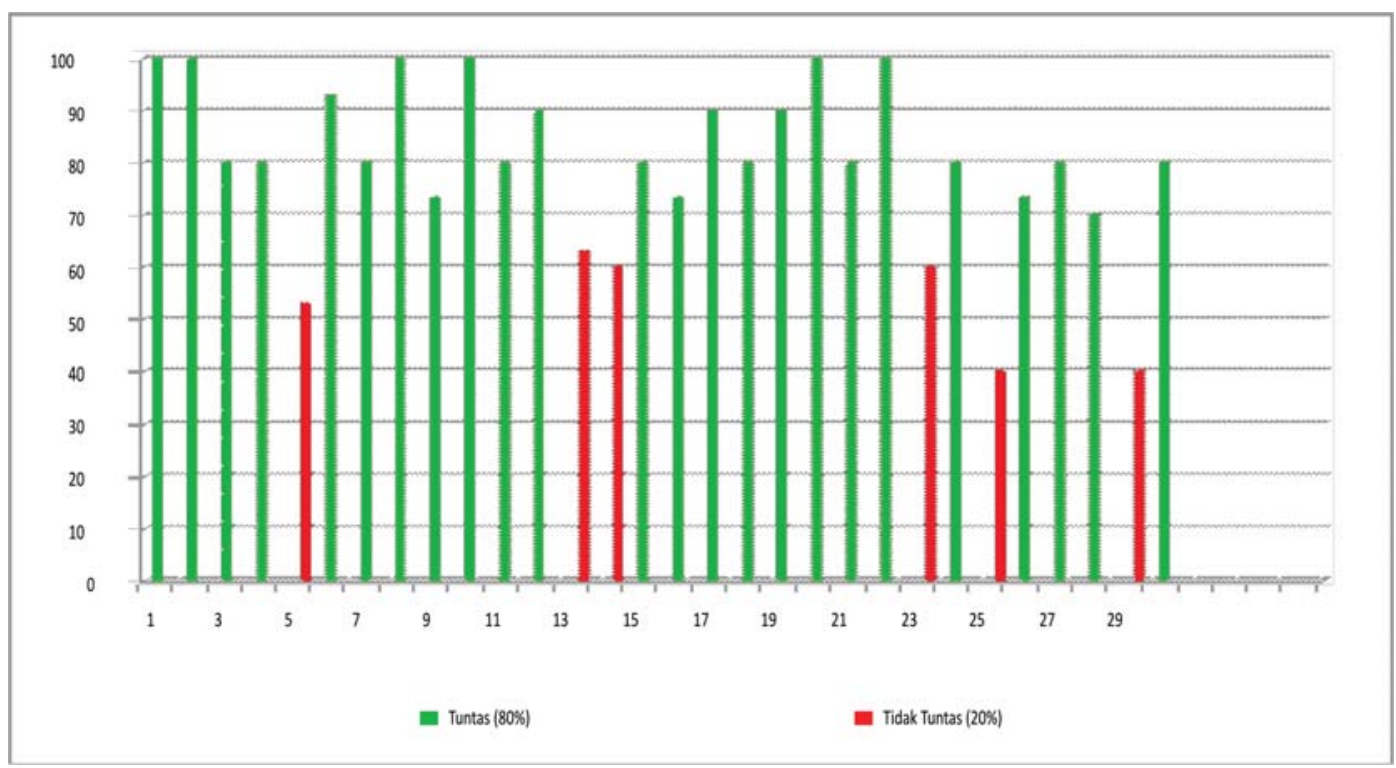

Grafik 1. Ketuntasan Pemahaman Konsep Siswa

Berdasarkan pada tabel dan grafik diatas dapat diketahui bahwa jumlah siswa seluruhnya yang mengikuti evaluasi adalah 30 siswa. Ketuntasan pemahaman konsep klasikal siswa adalah 75\% dari 30 siswa adalah $>22$ anak, sementara ketuntasan pemahaman konsep siswa sebesar 80\% > $75 \%$, maka siswa dinyatakan tuntas pemahaman konsep secara klasikal. Siswa yang memiliki hasil belajar yang tinggi atau diatas KKM belum tentu memiliki pemahaman konsep yang baik pula. Siswa 
yang tidak tuntas untuk pemahaman konsep kebanyakan salah pada jawaban soal essay. Pemahaman konsep penting bagi siswa karena dengan memahami konsep yang benar maka siswa dapat menyerap, menguasai dan menyimpan materi yang dipelajarinya dalam jangka waktu yang lama. Menurut Karolina (2009), pemahaman konsep merupakan kemampuan untuk menangkap dan menguasai lebih dalam lagi sejumlah fakta yang mempunyai keterkaitan dengan makna tertentu. Sedangkan menurut Sudijono (2008) meyatakan bahwa pemahaman konsep adalah kemampuan seseorang untuk mengerti atau memahami sesuatu setelah sesuatu itu diketahui dan diingat dengan kata lain.

\section{Hasil Belajar Siswa}

Berdasarkan hasil pengoreksian lembar jawaban soal tes formatif untuk hasil belajar siswa dapat diketahui bahwa masing-masing siswa memiliki hasil belajar yang berbeda-beda sesuai kemampuan siswa menerima pelajaran. Sesuai dengan indikator peningkatannya, siswa dikatakan memiliki nilai hasil belajar yang baik atau meningkat apabila nilai hasil tes formatif yang diperoleh siswa $>$ Standar Kelulusan Minimal (SKM) yaitu 70. Bagi siswa yang mendapat nilai pemahaman konsep dibawah SKM maka siswa tersebut dinyatakan tidak tuntas Jumlah siswa yang mengikuti evaluasi ada 30 anak.

Dari 30 siswa, ada 27 siswa yang memperoleh nilai tes formatif diatas SKM $>70$, sementara ada 3 siswa yang memperoleh nilai tes formatif dibawah SKM yaitu $<70$. Data tersebut selanjutnya dianalisis dengan menggunakan rumus ketuntasan hasil belajar untuk mengetahui persentase ketuntasan belajar klasikal siswa dapat dilihat pada tabel berikut:

Tabel 5. Data Nilai Ketuntasan Belajar Klasikal

\begin{tabular}{ccc}
\hline \multirow{2}{*}{ Prestasi Siswa } & \multicolumn{2}{c}{ Keterangan } \\
\cline { 2 - 3 } & Jumlah Siswa & Persentase \\
\hline Nilai $<70$ & 3 & $10 \%$ \\
Nilai $>70$ & 27 & $90 \%$ \\
Tuntas belajar & 27 & $90 \%$ \\
Tidak tuntas belajar & 3 & $10 \%$ \\
Jumlah siswa & 30 & \\
Rata-rata & 84,40 & $85 \%$ \\
Ketuntasan secara & $>25$ & \\
klasikal & & \\
\hline
\end{tabular}

Berdasarkan data diatas diketahui bahwa jumlah siswa seluruhnya yang mengikuti evaluasi adalah 30 siswa. Ketuntasan belajar klasikal siswa 85\% dari 30 siswa adalah $>25$ anak, sementara ketuntasan belajar siswa sebesar 90\% > $85 \%$, maka siswa dinyatakan sudah tuntas belajar secara klasikal. 


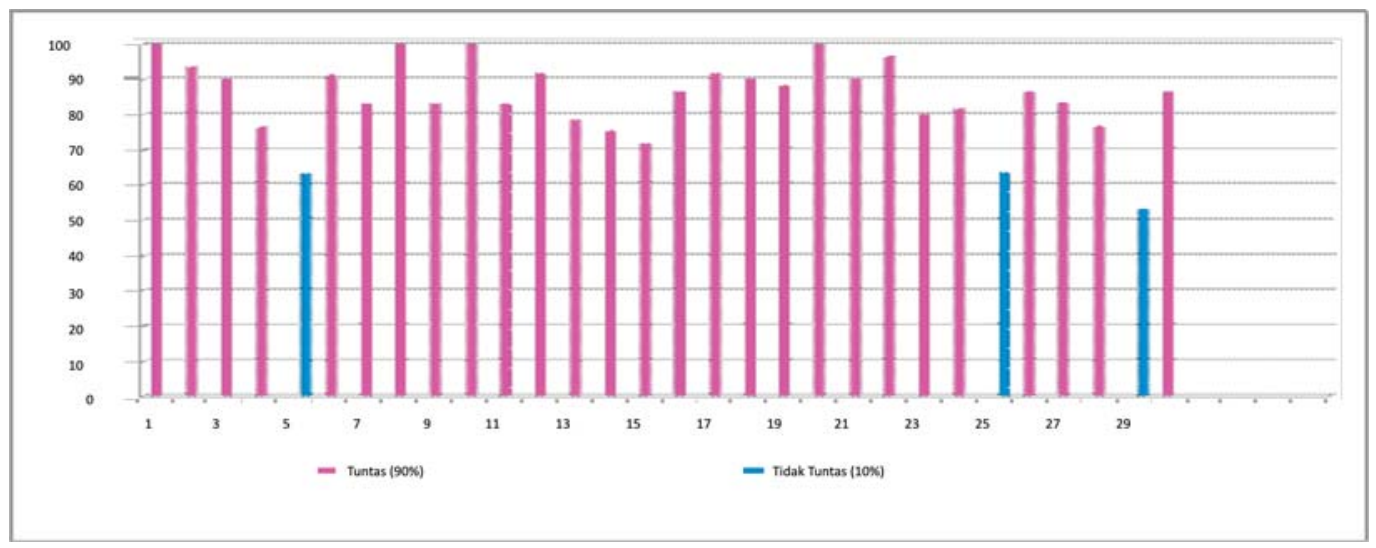

Grafik 2. Ketuntasan Nilai Hasil Belajar Siswa

Perbandingan Persentase Aktivitas Guru pada LS pertama, LS kedua dan PTK

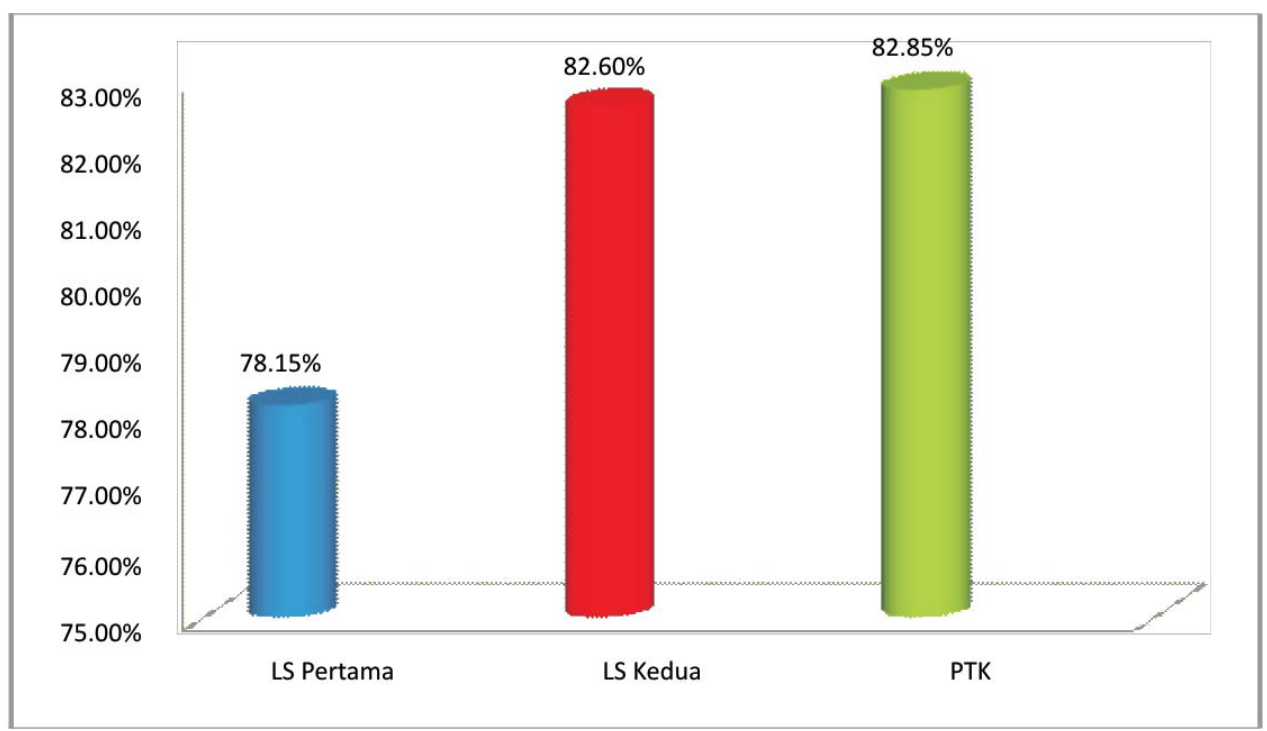

Perbandingan Persentase Aktivitas Siswa pada LS pertama, LS kedua dan PTK

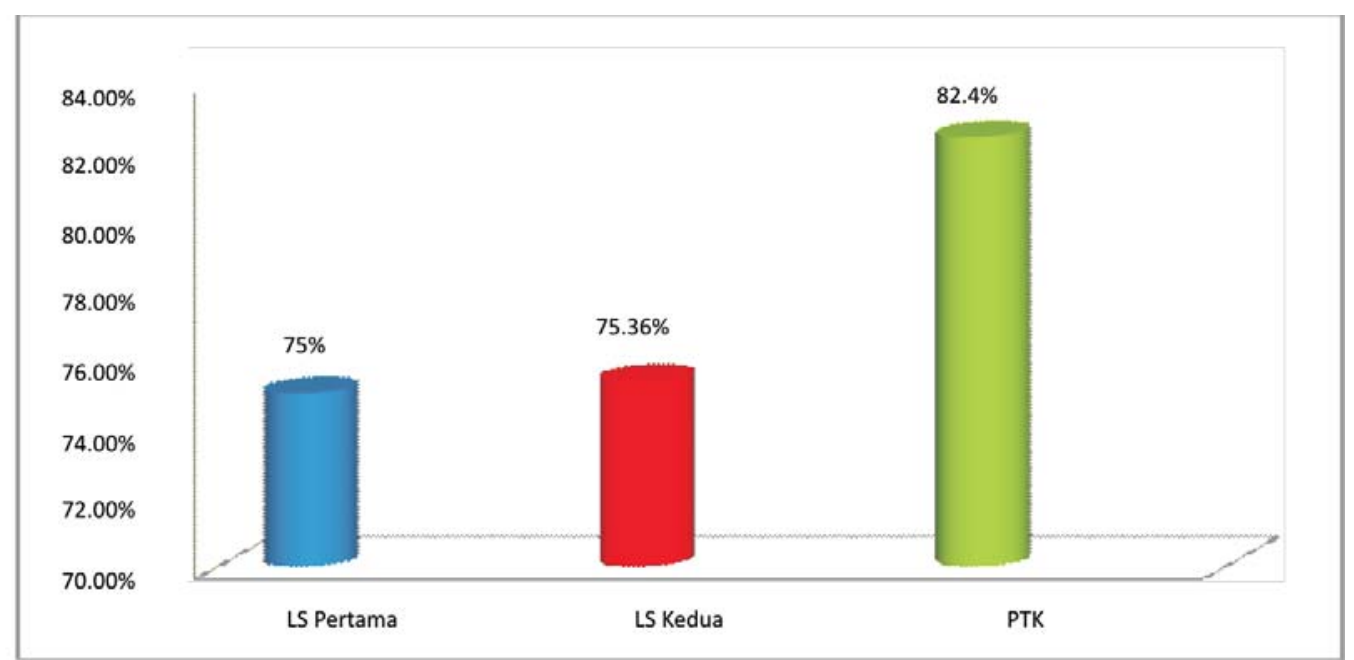

Citra Marina, Peningkatan Pemahaman Konsep dan Hasil Belajar Materi Penyesuaian Makhluk Hidup dalam Pembelajaran Kooperatif Tipe Think-Pair-Share Dipadu dengan Model Picture and Picture yang Dikembangkan Melalui Lesson Study 
Terlihat kemajuan siswa yang sangat baik dari awal pelaksanaan LS hingga tahap tindakan, baik aktivitas guru maupun aktivitas siswa juga terus meningkat. Pada LS pertama, keterlaksanaan sintaks pembelajaran belum optimal, ada 2 sintaks terlaksana kurang baik. Berdasarkan kriteria yang ditentukan bahwa pembelajaran dikatakan optimal apabila dari 8 sintaks perpaduan minimal 7 sintaks terlaksana dengan baik. Pada LS kedua, ada sedikit perubahan sintaks dari sintaks sebelumnya. Keterlaksanaan sintaks pembelajaran pada LS kedua sudah optimal karena pada pelaksanaan LS kedua merupakan perbaikan dari upaya optimalisasi pelaksanaan LS pertama. Dari 9 sintaks pada pembelajaran LS kedua, 8 sintaks sudah terlaksana dengan baik. Tetapi tetap harus dilakukan upaya optimalisasi sintaks yang terlaksana kurang baik tersebut pada tahap tindakan, sehingga pada pelaksanaan tindakan merupakan RPP yang sudah valid dan diharapkan semua sintaks terlaksana dengan baik. Hal tersebut terbukti bahwa pada pelaksanaan tindakan, semua sintaks terlaksana dengan baik.

Penerapan pembelajaran TPS yang dipadukan dengan model P\&P berorientasi pada kemampuan pemahaman konsep dan hasil belajar siswa, ternyata sangat efektif untuk meningkatkan aktivitas siswa. Perpaduan TPS dengan model P\&P sangat mendukung khususnya untuk pembelajaran di Sekolah Dasar. Media gambar memiliki peranan penting dalam meningkatkan hasil belajar siswa. Hal ini mengacu pada pernyataan Winataputra (2005) dalam Hamdani (2010), yang menyatakan bahwa penglihatan (visual) memiliki komposisi yang paling besar (75\%) dalam hal ratarata jumlah informasi yang dapat diperoleh seseorang. Informasi yang diperoleh melalui penglihatan juga lebih mudah ditangkap dan diingat oleh memori seseorang. Hal ini dapat dilihat dari hasil penempelan gambar dan pengisian tabel penyesuaian makhluk hidup berdasarkan hasil diskusi kelompok dan dipresentasikan di depan kelas. Ratarata persentase aktivitas siswa dari lima indikator penilaian selama proses pembelajaran tahap tindakan $=82,4 \%$ berada pada kategori baik. Lima indikator tersebut adalah: siswa aktif mengikuti pembelajaran sampai selesai, interaksi antar siswa dalam berpasangan, interaksi siswasiswa antar pasangan, interaksi siswa dengan guru, dan interaksi siswa dengan media pembelajaran. Persentase aktivitas siswa berada pada kategori baik ini disebabkan karena siswa sudah memiliki pengalaman sebelumnya pada pelaksanaan LS pertama dan kedua dalam mengikuti tahapan-tahapan pembelajaran TPS yang dipadukan dengan model P\&P.

\section{SIMPULAN}

Penerapan pembelajaran kooperatif tipe Think-Pair-Share (TPS) yang dipadukan dengan model Picture and Picture (P\&P) untuk peningkatan pemahaman konsep dan hasil belajar biologi dapat disimpulkan sebagai berikut: (1) Guru memberikan pertanyaan terkait materi dan memberi kesempatan kepada siswa untuk berpikir; (2) Guru mengorganisasikan siswa untuk berpasangan; (3) Guru membagikan gambar serta kertas buffalo yang sudah terdapat tabel penyesuaian diri tumbuhan; (4) Guru menugaskan siswa bersama-sama berdiskusi untuk menempelkan gambar dan mengisi tabel yang sudah tersedia pada kertas buffalo dengan membaca buku pelajaran; (5) Guru meminta kepada beberapa pasangan untuk berbagi/ presentasi hasil diskusi; (6) Guru menanyakan alasan pemikiran gambar 
yang sudah ditempelkan sesuai isian tabel; (7) Dari alasan pemikiran siswa, guru mulai menanamkan konsep sesuai kompetensi yang akan dicapai; (8) Guru memberikan kesimpulan.

Peningkatan pemahaman konsep dan hasil belajar melalui penerapan pembelajaran TPS yang dipadukan dengan model P\&P dapat disimpulkan sebagai berikut:

- Berdasarkan data hasil pengkoreksian lembar tes formatif khusus soal-soal tingkatan C2, untuk pemahaman konsep siswa pada pelaksanaan tindakan, siswa yang memperoleh nilai $<70$ sebanyak 6 orang (20\%), sedangkan yang mendapat nilai $>70$ sebanyak 24 orang (80\%) dari 30 siswa yang mengikuti evaluasi.

- Berdasarkan data hasil pengkoreksian lembar tes formatif untuk semua tingkatan soal C1-C4, untuk hasil belajar siswa, siswa yang memperoleh nilai > SKM sebanyak 27 orang (90\%), sedangkan yang mendapat nilai $<$ nilai SKM sebanyak 3 orang (10\%) dari 30 siswa.

Berdasarkan kesimpulan di atas, maka peneliti ingin menyampaikan beberapa saran yang dapat dijadikan pertimbangan untuk perbaikan proses pembelajaran yang selanjutnya antara lain:

1. Penerapan pembelajaran kooperatif tipe TPS yang dipadukan dengan model P\&P sebaiknya sesuai dengan materi yang memiliki konsep-konsep terkait lingkungan sehari-hari dan materi yang membutuhkan media gambar sebagai media pembelajaran.

2. Membuat soal untuk tes formatif yang terkait kehidupan sehari-hari agar siswa dapat berpikir lebih kritis dan dikaitkan dengan gambar-gambar sehingga menarik bagi siswa. Soal tes formatif yang dibuat dapat mencakup tingkatan C1-C6.

\section{DAFTAR PUSTAKA}

Hamdani, 2010. Efektifitas Pemanfaatan Media Gambar dalam Peningkatan Hasil Belajar pada Pembelajaran Sholat (Skripsi). Sekolah Tinggi Agama Islam DR. Khez Muttaqien Purwakarta

Ibrahim, M., Rachmadiarti, F., Nur, M., \& Ismono. 2000. Pembelajaran Kooperatif. Surabaya: University Press.

Isjoni.2010. Cooperative Learning Efektifitas Pembelajaran Kelompok. Bandung: Alfabeta.

Karolina, 2009. < http://lib.atmajaya.ac.id/ default.aspx?tabID $=61 \& s r c=k \& i d=$ 154739>. Diakses 23 Desember 2011

Kurnaeni, E. 2008. Upaya Meningkatkan Pemahaman Konsep Bilangan Bulat dengan Menggunakan Alat Pesraga. Bandung:Skripsi FPMIPA UPI

Mulyasa. 2009. Praktik Penelitian Tindakan Kelas. Bandung: PT Remaja Rosdakarya

Spark, Dennis. 1999. Using Lesson Study to Improve Teaching. (Online). <http://www.learningpt.org/msc/ products/tot.htm diakses 10 Oktober 2011>

Sudijono, Anas. 2008. Pengantar Evaluasi Pendidikan. Jakarta: PT. RajaGrafindo Persada.

Sudjana, N. 2005. Penilaian Hasil Proses Belajar Mengajar. Jakarta: PT. Raja Grafindo Persada.

Sudrajat, A. 2008.Lesson Study untuk Meningkatkan Proses dan Hasil Pembelajaran. (Online). (http:// akhmatsudrajat.wordpress.com) diakses tanggal 24 Juni 2011.

Supriyono, A. 2009. Cooperative Learning Teori Aplikasi \& Aplikasi Paikem. Yogyakarta: Pustaka Pelajar Yusti, arini.2009. http://yusti-arini. blogspot.com/2009/08/modelpembelajaran-kooperatif.html 